\title{
Unearthing Elements of Successful Park Master Planning: A Case Study of Belle Isle Park, Detroit, Michigan
}

\author{
Hanbing Liang, Pat Crawford \\ Michigan State University, East Lansing, MI, USA \\ Email: liangha1@msu.edu,crawf203@msu.edu
}

How to cite this paper: Liang, H., \& Crawford, P. (2018). Unearthing Elements of Successful Park Master Planning: A Case Study of Belle Isle Park, Detroit, Michigan. Current Urban Studies, 6, 21-36. https://doi.org/10.4236/cus.2018.61002

Received: December 12, 2017

Accepted: March 6, 2018

Published: March 9, 2018

Copyright (C) 2018 by authors and Scientific Research Publishing Inc. This work is licensed under the Creative Commons Attribution International License (CC BY 4.0).

http://creativecommons.org/licenses/by/4.0/

Open Access

\begin{abstract}
Does a well-designed master plan guarantee the future of a park? The answer to this question is not certain, which leads to asking what other factors contribute to the success or failure of master planning? Having a blueprint to guide the development of a park, often called a master plan, is commonly accepted as integral to park development. Belle Isle Park is the largest public park in Detroit. Since its establishment in 1880, the park has gone through dramatic social and economic changes, along with the City of Detroit. This case study takes Belle Isle's unique history to identify possible factors that are significant to park development and success or failure of master planning. Despite the four master plans that were created for Belle Isle (by Frederick Law Olmsted, Dan Kiley and other design firms), the master plans did not significantly influence the actual growth of the park. Through this case study, four major factors, beyond good design, were identified that need to be taken into consideration throughout the entire process. These factors include: 1) permeability of location, access and spillover; 2) concordance of purpose, interests and decisions; 3) milieu of influencers, ideologies and consequences; and 4) connectedness of engagement, support and pride.
\end{abstract}

\section{Keywords}

Urban Planning, Park Master Planning, Landscape Architecture

\section{Introduction}

Belle Isle, the largest island city park in the US, is the gem of Detroit, serving residents and visitors since 1880. Situated in the Detroit River between Detroit, Michigan and Windsor, Canada, the 900 -acre park provides a blend of green 
space, water access and active recreational amenities (Anderson, 2001). The history of Belle Isle Park provides a unique glimpse into park planning.

Park master planning, often called general management planning, is a technique used by planners and designers to create a clear and consistent framework for park development and use over time. It is still one of the most commonly practiced planning approaches (Madden, 2001; Harnik, 2006) and provides a development blueprint as guidance for many aspects of the park, including social, environmental, economical, and historical. The inventory and analysis of a master plan, provide a foundation for the long-range plans so that they are appropriate for the site and surrounding community. A successful master plan includes an understanding of the context, is based on available data and knowledge, makes spatial, resource, and social connections, and is broad enough to work over a period of time (Pack \& Schanuel, 2005).

The approach to park planning is continually evolving in response to social needs. Design process and public participation were not considered part of the master plan until the 1970s (Levy, 2009). The major social drivers leading to understanding the importance of process and participation in master planning include events such as the Great Depression, the Federal Highway Act, Urban Renewal, and Jane Jacobs' influential planning philosophies (Hall, 2002). Successful park development cannot rely solely on having a great master plan; engagement, collaborations and strategies to build support are also important factors for success (Leone, Barnes, \& Sharpe, 2015).

A case study approach is used to explore the history of master planning for Belle Isle Park, the park's relationship to Detroit, and the impacts of national trends. With the rise and fall of Detroit, Belle Isle Park has gone through many social and physical changes. After 133 years as a city park, the management of Belle Isle was transferred to Michigan State Parks, Department of Natural Resources, following the declaration of bankruptcy by the city of Detroit in 2013 (Michigan Department of Natural Resources, 2014).

While several master plans have been created throughout the history of Belle Isle Park, the benefits associated with master planning have not been realized. This study aims to explore the reasons that led to the failures in implementing master plans for Belle Isle, and to identify the possible forces that caused the park's transformation. The significance of this work is to help us better understand how to create successful master planning processes. With the assumption that "successful" events often mask weakness in a system, studying a "failed" case allows for unearthing the critical elements or factors. The length of time that Belle Isle has been a park also allows for exploring critical factors within the context of historical events and assists with parsing out ephemeral, or short lived, influences.

The case study traces the history of Belle Isle Park planning and development in chronological order, from purchase of the island to when Detroit filed bankruptcy and transferred management of the park to the state. The impacts of so- 
cial movements and the history of Detroit itself are woven into the narrative. Four critical factors for successful master planning emerged from the Belle Isle experience: permeability, concordance, milieu, and connectedness. Each of these is discussed in detail in the conclusion.

\section{Development of Belle Isle}

\subsection{Purchase of Belle Isle}

During the nineteenth century, cities experienced unpredictable transformations resulting from the industrial revolution (Muller, 1995). Factories became the central workplace for many individuals. Working hours were extended to more than 12 hours per day. Pollution, housing conditions, and environmental and health hazards were serious urban issues (Frumkin, Frank, \& Jackson, 2004). Public parks were created to provide recreational opportunities in between the long working hours, and to bring back the feeling of the countryside to depressed urban dwellers (Garvin, Public Parks: The key to livable communities, 2011). Metropolitan cities like London, Paris, New York, and Boston built large public parks in succession. As a rising manufacturing city in the Great Lakes region in the 1850s, Detroit also considered creating a public park for its people, and to establish its national political and economic status (Anderson, 2001).

The Detroit City Council initiated a plan to purchase a park in the 1870s. The choice of public park location was debated between Belle Isle island and a large piece of vacant land in central Detroit. The process of selecting a park location was controversial since the beginning of park discussions. At the time, Belle Isle was privately owned, with only one building structure that existed on the island (Justus, 2002). Local dignitaries and entrepreneurs wanted to purchase the island and convert it into a switching yard, for better logistics and trade between Detroit and Canada. As population grew over time, the city was concerned with the provision of fresh water facilities for public access and recreation. A fresh water intake was suggested by the city Mayor, George C. Langdon, to be built on the island. In 1879, the city council announced that Belle Isle was to become a public park without any advanced notice. According to historic newspaper articles, many local people voiced concerned over the decision because it was run by private interests and the park was inaccessible from mainland Detroit. The purchase of Belle Isle cost $\$ 200,000$, and the city raised money by selling bonds because the local government had difficulties in allocating the funds (Rodriguez \& Featherstone, 2003).

\subsection{The First Master Plan}

After the purchase of Belle Isle, the City of Detroit was in need of a possible park development master plan. In 1883, the Belle Isle Park Commission appointed Frederick Law Olmsted as the chief landscape architect for Belle Isle to generate a comprehensive master plan (Figure 1). By that time, Olmsted was in the later 


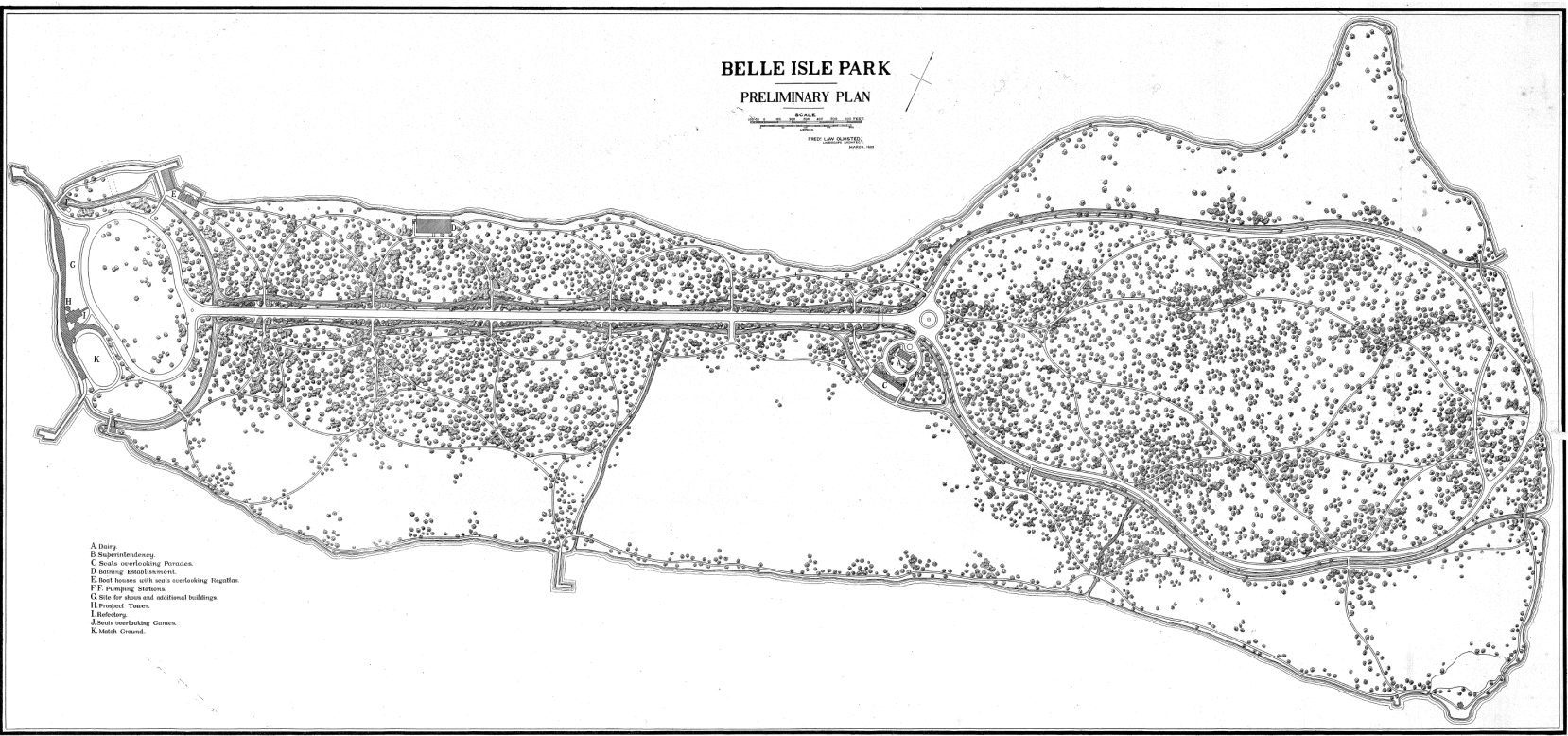

Figure 1. Master plan by Frederick Law Olmsted (Image credit to Michigan DNR archive files).

stages of his career, as he retired in 1895. It had been over 20 years since Olmsted designed Central Park and many other prominent parks thereafter (Beveridge, 2000). It was not an easy collaboration between Olmsted and the City of Detroit since the beginning of his appointment. He observed the city's financial difficulties in allocating funding sources for the park. The plan proposed by Olmsted, "was more of a plea than a blueprint" (Rodriguez \& Featherstone, 2003: p. 26).

The design he proposed included a ferry dock, a pavilion spanning the west end of the island, a parade ground, and a central boulevard (Figure 2). To Olmsted, the natural old growth forests were the most precious assets of Belle Isle, which he insisted must be preserved. The plan was initially approved by the city, but after a year, the city rejected the idea of having a "gallery" that connects to the dock and spans the west end of the island. Olmsted tried to seek support from local dignitaries and government officials by convincing them the gallery would be necessary for future use to accommodate needs from all people and for all purposes. This was the only major structure he proposed on the island. Other components of his plan suggested passive park usage. Olmsted had urged that if this part of the plan was not accommodated, it would very likely result in a more burdensome expenditure for other park accommodations in the future (Olmsted, 1884: p. 14).

Despite all his efforts to convince the city council and park commissioners to adopt his ideas, the city council refused to listen to Olmstead's suggestions and instead thought that implementing the gallery was too expensive (Olmsted, 1884). Olmsted resigned from the project in 1885, before the expiration of his contract. Later when he was asked about the stewardship of Belle Isle, he said "I know nothing of that place" (Rodriguez \& Featherstone, 2003: p. 26). His idea of 


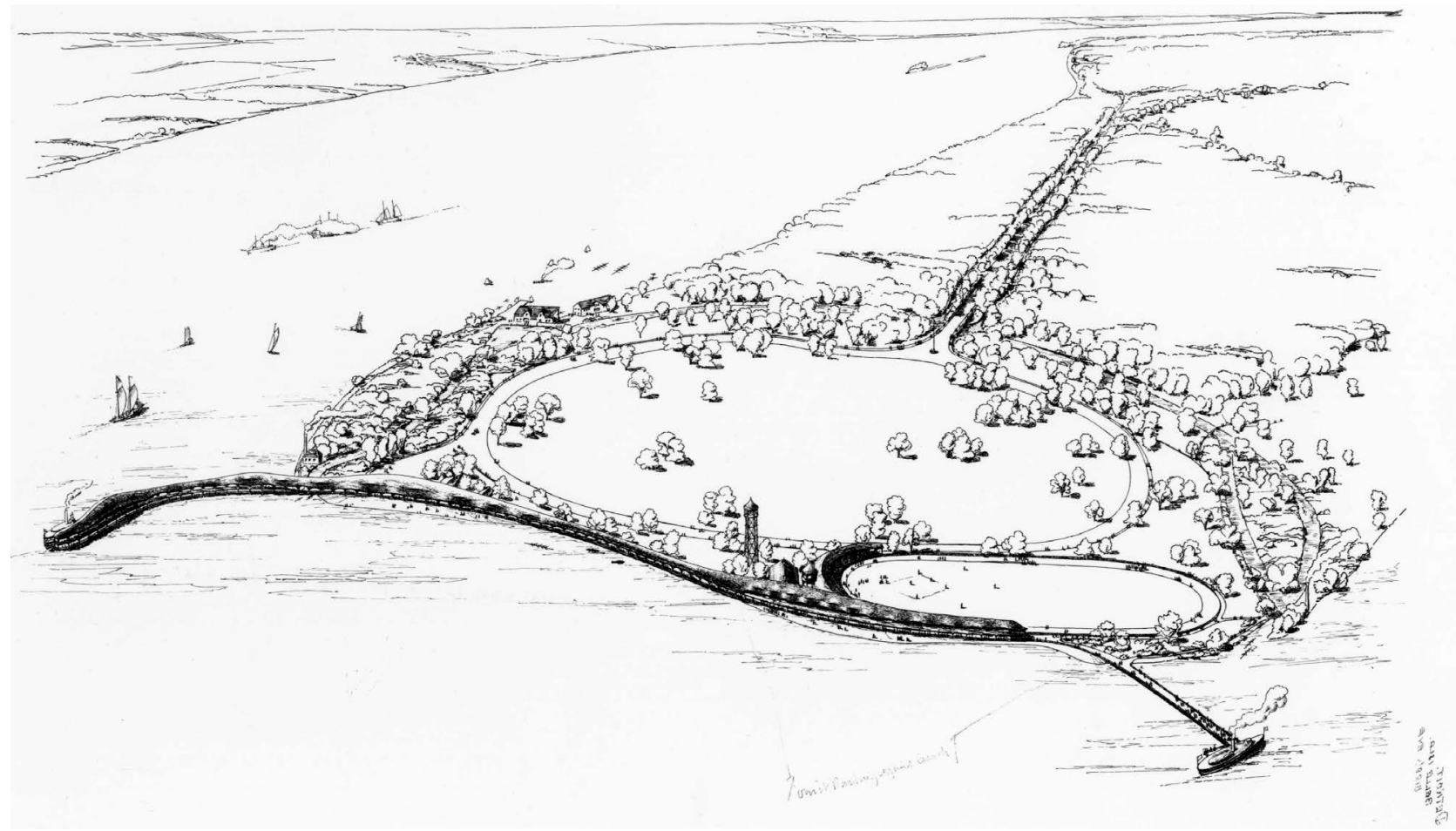

Figure 2. Drawing of ferry dock, pavilion, parade ground and a central boulevard by Frederick Law Olmsted (Image credit to Michigan DNR archive files). 
Windsor, departing from the same location, cost 5 cents. The riverfront of Detroit has been a business corridor since the early 1800s. Many shipyards and factories were built along the banks of the Detroit River. Most of the housing in Detroit was developed towards the inner city (Rodriguez \& Featherstone, 2003). The physical developments on mainland Detroit did not benefit from spillover economics from the establishment of the island park. An abundance of research has studied the relationship between urban green spaces with residential property values or business activities (Garvin, 1996; Pack \& Schanuel, 2005). This research has generally found that a residential development that is adjacent to a park or green space tends to attract more residents and generates higher property values (Garvin, 2011). Central Park is a great example, where the businesses and properties around the park have definitively higher housing or rental prices, since the park has naturally become part of their commercial assets. The properties around these natural areas then pay higher taxes back to the city (McNeur, 2017). But none of these benefits apply to Belle Isle, due to its geographic situation. As an island park sitting in Detroit River, there is no physically significant relationship between the park and the rest of developments taken place in Mainland Detroit. The lack of physical adjacency, or shared borders, decreased the potential benefits to Detroit property owners and businesses from the park. This is in contrast to other urban parks in Detroit, like Campus Martius Park or Dequindre Cut, which have brought potential economic benefits to nearby properties (Michigan Municipal League, 2013). With no additional spillover economics from Detroit to offset the cost of Belle Isle, the island itself has certainly become the spot for investment and development.

\subsection{Boom of Detroit}

In the early 1900s, Detroit went through a great economic boom from the auto industry. People flooded into the city in search of new jobs and better opportunities (Sugrue, 2007). Belle Isle became even more popular as a recreational destination. Between 1900 and 1920, many structures were added to the island's development, including the Detroit boat clubhouse, aquarium, conservatory, the second casino, picnic shelters, bath houses, Detroit Zoo, and the golf course (Anderson, 2001). During this period of time, the developments shared great similarity with the nation's other large public parks. The Central Park Zoo was created in the 1860s. The conservatory at Golden Gate Park in San Francisco was opened in 1879, which is very similar to the conservatory on Belle Isle in terms of design and function. Once swimming and bathing were introduced into parks, they soon became some of the most popular activities (Cranz, 1989). Large parks incorporated bath house facilities, where the bath house on Belle Isle was once the largest in the nation (Rodriguez \& Featherstone, 2003).

Private interests continued pouring into the park land. In 1915, About 200 acres of fill were added to the Western tip of the island when the city received a donation of James Scott's entire fortune, a local real estate speculator who had a 
bad reputation related to his business and personal life. By accepting the fortune, a memorial statue of James Scott was placed in the park. Though its placement was controversial, the city accepted the money and went on with construction. Many local entrepreneurs and dignitaries wanted to donate sculptures or statues to be placed on the island. The park commission agreed to only placing statues along the Central Avenue, which would not be too much of an intrusion into the park's natural environment (Rodriguez \& Featherstone, 2003). Contrary to local perception, most of the park designers or commissioners were very much against the placement of statuary in parks, partially due to the resemblance to the European aristocratic style gardens and its appropriateness for different classes of people.

During the Second World War era, the increasing patriotism in the United States stimulated many other uses for public parks. Parks became active in accommodating the needs of military services. Park programming also shifted the focus from leisure to recreational services with a sense of patriotism. For sports and physical activities, people tended to train harder during war time. Handicraft programs were popular during the Depression, where people were encouraged to make things that could sell. Large communities gathered and recycled materials to develop creative and useful products. The craft making process also helped release tension during war time (Cranz, 1989). Belle Isle was also used as a military base at the time, just like many other public parks in the country (Rodriguez \& Featherstone, 2003).

After the war, America entered the age of the baby boomer, where large numbers of people returned to the city in search for housing opportunities. The inner cities were not capable of providing and extensive amount of housing. The Urban Renewal program of 1949 enacted large slum clearance projects in major metropolitan cities. The National Defense Highway Act of 1956 also facilitated large scale urban sprawl (Hall, 2002). Even though Detroit's population reached its peak of 1.8 million in the 1950s, the racial distribution was already shifting. Major automobile factories relocated to the suburbs due to the increasing tax in the City of Detroit. The middle and upper class residents, which are mostly white families, had gradually moved from the inner city to the outer fringe for better housing and job opportunities. Most of the designated slum neighborhoods were in the downtown area, which hosted large numbers of African American residents. The practice of redlining with financial loans restricted the lending of money in African American neighborhoods. As a result, minorities with low income were trapped in the old housing stock in the city. When the city government used eminent domain to remove the residents who lived in the areas designated as slums, a lack of compensation and assistance provided for housing alternatives resulted in a great deal of homelessness. In the 1960s, most of the white residents in Detroit moved to the outer fringe of the city or nearby suburbs from the inner city. Downtown Detroit and the inner city transitioned from white to black neighborhoods (Sugrue, 2015). 


\subsection{Decline of Detroit}

The downfall of Detroit's auto industry started in the 1950s, when major automobile plants shut down in the city and moved to the suburbs. The development of automation replaced some of the need for labor and led to more than 300,000 layoffs in the auto industry (Sugrue, The Origins of the Urban Crises, 2015: p. xvi). The flight of jobs from the inner city significantly reduced the tax base of the city. The race riot of 1967 was often considered a turning point in Detroit's history (Sugrue, 2007). Similar social unrest happened in other cities during the 1960s, which completely changed the image of urban life in the eyes of Americans. City parks, instead of a place for leisure and cure, became spaces to engage in conflict and crime (Cranz, 1989). People who had the ability to move fled immediately out of the city, regardless of race and ethnicity (Sugrue, 2015).

Reduction in the budgets of public sector works was often the first set of actions that the government took after economic decline. The skating pavilion located north of Lake Tacoma was replaced by the Flynn Pavilion in 1950 (Gay, 2013). The Detroit Zoo moved to Royal Oak in 1956, and the previous Belle Isle Zoo was renamed the Children's Zoo and downsized (Rodriguez \& Featherstone, 2003). Parks and park departments across the nation experienced similar budget reductions and layoffs, which resulted in lack of maintenance, deterioration of facilities, and safety issues (Harnik, 2006).

\section{Belle Isle's Attempts to Recover}

\subsection{Master Plan by HCMA}

In 1972, the city was about to transfer the authority and management of Belle Isle to the Huron Clinton Metropolitan Park Authority (HCMA). The plan proposed by HCMA (Figure 3) asked for a large sum of investment, approximately $\$ 40$ million, which required a half-million increase in taxes. The request was rejected by a large margin of voters. It was argued that the development of HCMA parks was based on a large share of Detroit's tax base from the start, but all of their parks were not within the city, and not accessible via public transportation (Zanen, 1972). During the process, HCMA initiated a pilot study that sent out surveys to park commissioners across the nation for input on park development. Little data was collected from local residents, and the master plan developed by HCMA remained very much unknown to the general public (Chubb, 1972).

\subsection{Master Plan by Dan Kiley}

In 1976, the Friends of Belle Isle, the Junior League of Detroit, and the Junior League of Birmingham hired landscape architect Dan Kiley to develop a schematic design for Belle Isle (Figure 4). The work was paid for by the above organizations in the sum of $\$ 50,000$, instead of the City of Detroit (Detroit Free Press, 1975). The plan called for a ban on automobiles on the park property when it was first initiated, which caused enormous public opposition. In the 


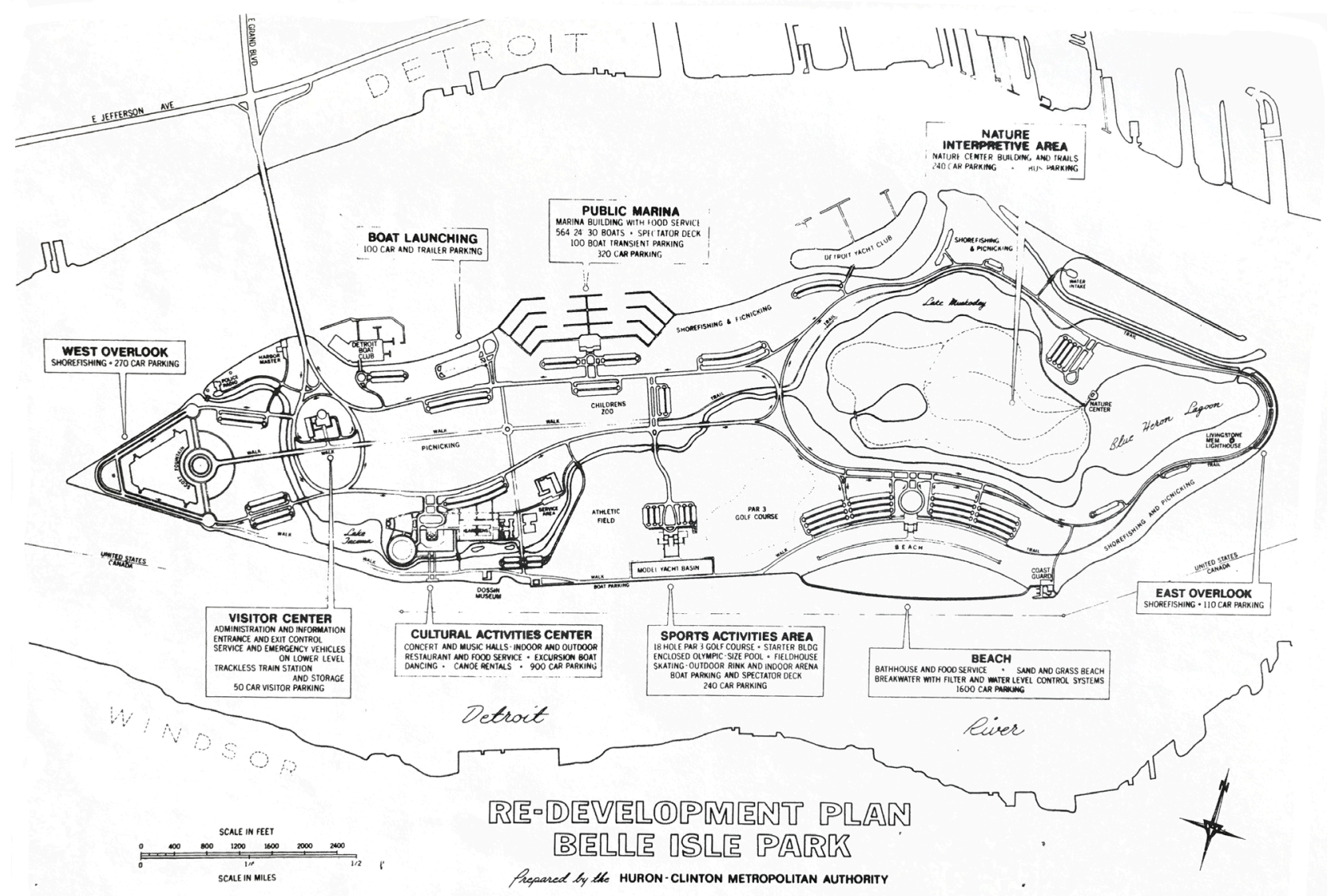

Figure 3. Master plan by Huron Clinton Metropolitan Park Authority (Image credit to Michigan DNR archive files).

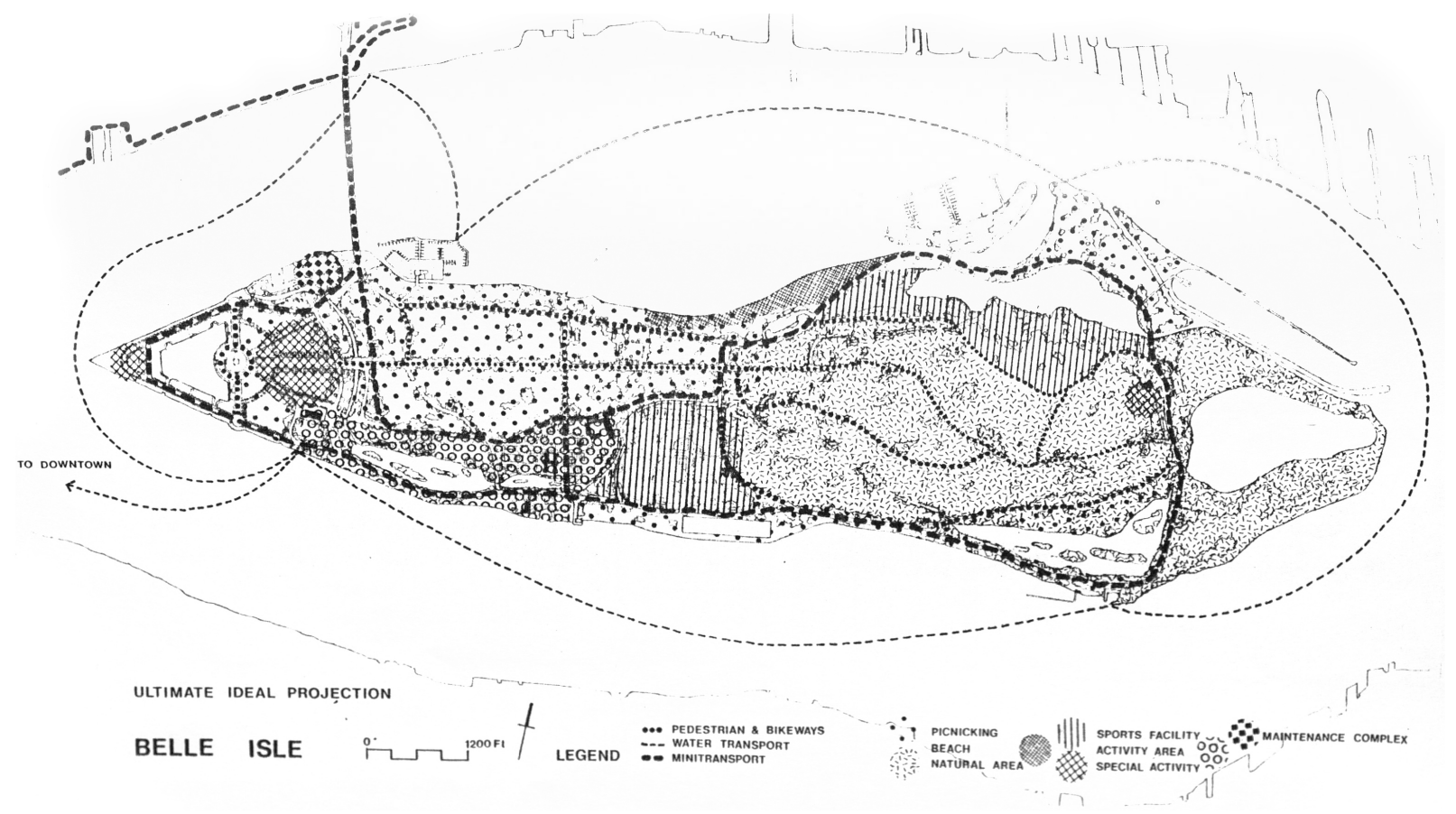

Figure 4. Master plan by Dan Kiley (Image credit to Michigan DNR archive files). 
following year, Dan Kiley was not insistent with the idea on banning automobiles. He provided a phasing plan, which was more of a return to Olmsted's original idea by accepting the existing conditions. The plan introduced alternative transportation options including bus, water taxis, and ferries. The phases could help the park and the users to gradually adapt to public transportation, instead of relying solely on cars (Kiley, Tyndall, \& Walker, 1976). There were also many recommendations made about park maintenance, but only a few were implemented based on the plan, including the renovation of the back of the Casino. The reason for the low implementation of park maintenance plans was possibly due to the city's financial difficulties (Hamilton Anderson Associates, 2006).

\subsection{Master Plan by Hamilton Anderson Associates}

In 1996, the City of Detroit's Department of Parks and Recreation worked together with Hamilton Anderson \& Associates in creating a comprehensive master plan for Belle Isle (Figure 5), along with a technical assessment report. The design process involved a couple of sessions with public participation, where local residents shared their thoughts with the landscape architects. The plan was presented to the City Council in 1998, and delivered to the neighborhood for public participation in 1999. An update of the master plan was presented to the city in 2005, with information regarding changes in recent years (Hamilton Anderson Associates, 2006). However, the plan was never adopted by the City of Detroit,

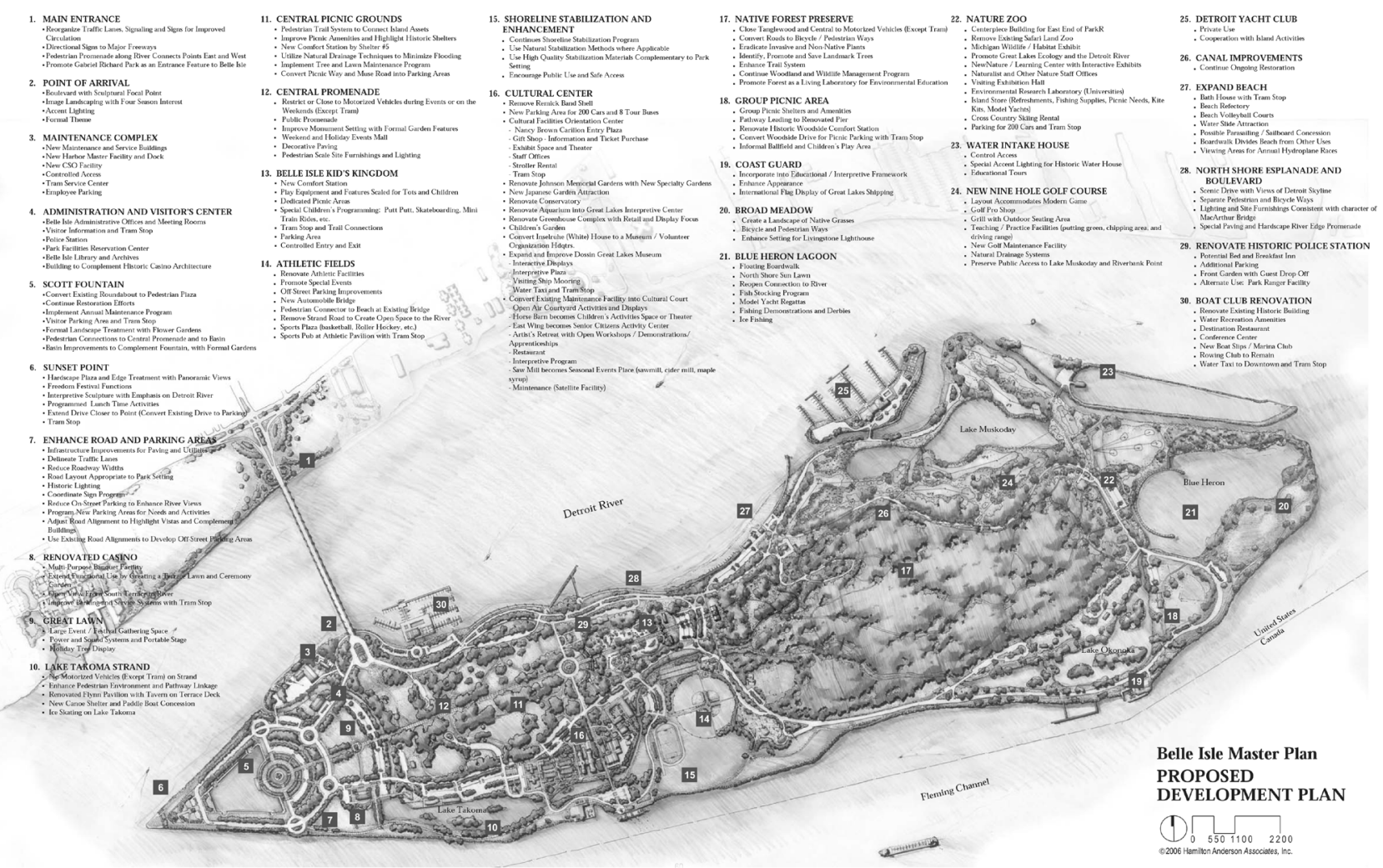

Figure 5. Master plan by Hamilton Anderson Associates (Image Credit to Michigan DNR archive files). 
possibly because of the large cost that would be required to implement the plan, which was about $\$ 180$ million in the late 1990s (Gallagher, 2013).

\subsection{Detroit Filed Bankruptcy}

Several major structures on the island were in disrepair due to the lack of maintenance. The attendance to the aquarium continued declining in the 1990s, and was closed in 2005 for several years. The zoo, golf course, and driving range were closed with no plan for reopening. The Boat House was originally an elegant clubhouse, but had been deteriorating and vacant since 1980s, and similar conditions exist at the Athletic Pavilion (Rodriguez \& Featherstone, 2003). As the city of Detroit declared bankruptcy in 2013, the city was no longer capable of maintaining Belle Isle as a city park. The city signed a 30-year lease for Belle Isle with the Michigan Department of Natural Resources, which transferred the management and operation to the State, as it is still owned by the city (Michigan Department of Natural Resources, 2014).

\section{Results}

Through a case study of the history and development of Belle Isle, its relationship with Detroit, and national trends; four influential factors emerged. These are 1) permeability of location, access and spillover, 2) concordance of purpose, interests and decisions, 3) milieu of influencers, ideologies and consequences, and 4) connectedness of engagement, support and pride (Figure 6).

\subsection{Permeability: Location, Access, Spillover}

A park as a service facility requires engagement with people and social activities (Geoffrey \& Mowen, 2010). Location has a strong impact for the degree of permeability on both social and economic benefits. The park's location determines the accessibility of different groups of park users (Harnik, 2006). Belle Isle as an island park, with its location and distance from the city, was only accessible through water transportation to the general public in the early times. The ferry to Belle Isle cost 10 cents from Woodward Avenue in Detroit, whereas it only cost 5 cents from the same location to Windsor, Canada (Rodriguez \& Featherstone, 2003). The park's economic condition also has a direct relationship to its location, such as generating a locational spillover effect, where the businesses or properties within close distance gain indirect impacts from the targeted development

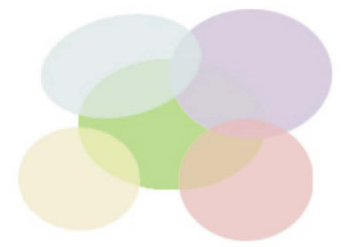

Permeability

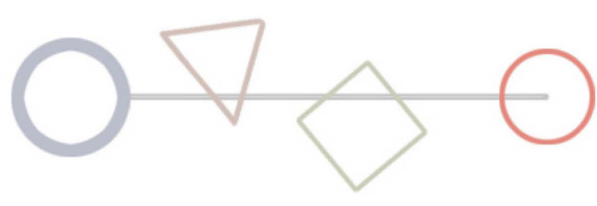

Concordance

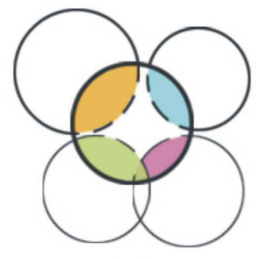

Milieu

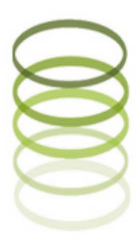

Connectedness

Figure 6. Permeability, concordance, milieu, and connectedness. 
(Garvin, Public Parks: The key to livable communities, 2011). Often times, park location is selected near neighborhoods or properties where the real estate close to the park would experience an increase in property value. Businesses and retail would generate greater revenue as more people visit or live near the park. Local government would then have an increase in the tax base from nearby properties (McNeur, 2017). Such income could later offset the city's early investment in park development and maintenance costs. This scenario does not apply to Belle Isle, as it is isolated from all other city developments and social atmospheres. The lack of spillover effects of Belle Isle resulted in many public and private interests to develop parts of the island. Strong permeability promotes social and physical linkages between a park and its users, not only for park visitors, but also the surrounding businesses, organizations, and political entities.

\subsection{Concordance: Purpose, Interests, Decisions}

The second factor that emerged from the analysis was the concordance of purpose, interests and decisions, for successful park development. Public parks are created to serve the public and people (Dahl \& Molnar, 2003). The basic purpose did not carry out along the continuing development of Belle Isle, at many periods of time. The purchase of Belle Isle as a public park did not involve any voice from the public in 1879, and was managed entirely by the city officials. At the turn of the century, "dignitaries and city businessmen often had as much or more influence in government affairs than the city's highest-ranking official" (Rodriguez \& Featherstone, 2003: p. 21). The purpose of purchasing Belle Isle was questioned by the general public, as many of the early developments and structures were reserved for private members of certain groups, including the Boat Club, Detroit Yacht Club, and Casino. The Casino was always leased to local restaurants and used as a place to hold private events (Rodriguez \& Featherstone, 2003). The fundamental purpose of a public park and its master plan is set to better serve ordinary citizens (Dahl \& Molnar, 2003; Garvin, 2011), which contradicts some of Belle Isle's developments. Agreements between Detroit residents, developers, and the government didn't line up to make Belle Isle a great public space for the general public of Detroit. Instead, the plans tended to focus on special interests, which didn't help to sustain the richness of Belle Isle Park and led to many development failures.

\subsection{Milieu: Influencers, Ideologies, Consequences}

The term "milieu" is defined as "the physical or social setting in which something occurs or develops" (Webster). Regarding Belle Isle, influencers, ideologies, and social and economical consequences are part of its milieu. Major nationwide urban movements had a strong impact on the development of Detroit, such as the City Beautiful Movement, the Great Depression, the New Deal, Urban Renewal, and National Highway Act (Levy, Contemporary Urban Planning, 2009). The services that people demanded from parks shifted between eras in 
response to different social changes. Public parks including Central Park in New York, Golden Gate Park in San Francisco, or the Chicago Park District have strong influences on trends in park development (Cranz, 1989). Many of the facilities on Belle Isle were erected around the same period of time as other major parks in the nation. The zoo, aquarium, conservatory, golf course, baseball fields, and bath houses were all a response to the national trends in the early $1900 \mathrm{~s}$. However, this trend discontinued when Detroit's auto industry started to decline in the 1950s.

In the late 1960s, the Urban Renewal program aroused public indignation, especially in New York, where projects in Lower Manhattan were terminated by public protest efforts. Jane Jacobs' theory about urban places proved to be very influential in the planning field nationwide and possibly worldwide (Alexiou, 2006). Advocacy planning and public participation became mainstream in urban planning theories after the 1970s (Levy, Contemporary Urban Planning, 2009). This new planning approach did not have much effect on the City of Detroit. Projects that took place following the termination of Urban Renewal were still a continuation of the same "slum clearance" ideology, which tried to attract the middle-class residents back to the city, rather than taking care of its own residents (Thomas, 2015). Belle Isle was no longer on the list that would have quick economic returns to the city. The cut in the public works budget led to the deterioration of not only Belle Isle, but also forced most of Detroit's public facilities to shut down (Rodriguez \& Featherstone, 2003). Because of the lack of a strong master plan, Belle Isle's identity was formed by special interest groups, where decisions were made for their own benefits. The ability to recognize the social background, and work with the unique park identity is vital to sustainable, resilient park development.

\subsection{Connectedness: Engagement, Support, Pride}

The fourth influential factor emerging from the study of Belle Isle was the social aspect of Connectedness. Over a century plus of park planning (1880-2013), citizen voices were either not sought or divergent opinions were dismissed. The first master plan for Belle Isle by Frederick Law Olmsted did not involve public input and the citizens of Detroit were not informed of the park plans. The decisions were made solely by government officials and local dignitaries. The later master plans in the 1970s started to provide opportunities to hear opinions from the public but were not successful in gaining much support from citizens. Drawing from these aspects of the Belle Isle story, connectedness is about engaging the public in appropriate and meaningful ways to foster citizen support and pride. Having strong public support and participation creates a sense of ownership and pride in residents who have been involved in the process. This not only ensures that the plan is made for the people, but also keeps the plan being constantly in the front of the mind of the general public for fostering continued attention and support (Lane, 2005; Harnik, 2006; Leone, Barnes, \& 
Sharpe, 2015).

\section{Conclusion}

The work adds to the body of literature and experience on how to craft successful master planning processes. By critically unearthing the weaknesses of this case, other scans use this knowledge to build strengths in their future work. Through the case study of Belle Isle, the four factors: 1) Permeability; 2) Concordance; 3) Milieu; and 4) Connectedness were identified through the review of the park's development, history and relationship with the city and nationwide movements. Belle Isle shares similar traits in the gradual process of development with other prominent public parks in the US, such as New York Central Park, San Francisco Golden Gate Park, etc. It also has its unique characteristics, the natural condition, geographic location, and culture influences, which may not be applicable to other public parks.

This work is limited in that it only explored one park, and the relationship between the park's master planning process and park development. If other parks that share similar condition with Belle Isle can be examined, the identified factors may become more prominent in context, and other factors may also emerge. Additional work to further expand on the identified factors could be useful for developing further depth to each of the concepts. Research could also focus on case studies of other large city parks in the US, testing the factors identified to see if they hold true in other contexts.

\section{References}

Alexiou, A. S. (2006). Jane Jacobs: Urban Visionary. Toronto, Ontario: HarperCollins Publishers Ltd.

Anderson, J. (2001). Island in the City: Belle Isle, Detroit's Beautiful Island. Detroit: Detroit Historical Museum.

Beveridge, C. E. (2000). Frederick Law Olmsted Sr., Landscape Architect, Author, Conservationist (1822-1903).

http://www.olmsted.org/the-olmsted-legacy/frederick-law-olmsted-sr

Chubb, M. (1972). Belle Isle Park User Pilot Study: A Report to the Huron-Clinton Metropolitan Authority. Detroit: Huron-Clinton Metropolitan Authority.

Cranz, G. (1989). The Politics of Park Design: A History of Urban Parks in America. Cambridge: MIT Press.

Dahl, B., \& Molnar, D. J. (2003). Anatomy of a Park: Essentials of Recreation Area Planning and Design. Long Grove, IL: Waveland Press, Inc.

Detroit Free Press (1975). Prettying Park: Landscape Architect to Study Belle Isle Face-Lift Potential. Detroit, MI: Detroit Free Press.

Frumkin, H., Frank, L., \& Jackson, R. (2004). Urban Sprawl and Public Health: Designing, Planning, and Building for Healthy Communities. Washington DC: Island Press.

Gallagher, J. (2013). Fixing Belle Isle. Detroit, MI: Detroit Free Press.

Garvin, A. (1996). The American City: What Works, What Doesn't. New York: McGraw-Hill. 
Garvin, A. (2011). Public Parks: The Key to Livable Communities. New York: W. W. Norton \& Company.

Gay, C. Y. (2013). Lost Detroit. London: Pavilion Books.

Geoffrey, G., \& Mowen, A. (2010). The Benefits of Physical Activity Provided by Park and Recreation Services: The Scientific Evidence.

http://www.nrpa.org/uploadedFiles/nrpa.org/Publications_and_Research/Research/Pa pers/Godbey-Mowen-Research-Paper.pdf

Hall, P. (2002). Urban and Regional Planning. New York: Routledge.

Hamilton Anderson Associates (2006). Belle Isle Master Plan. Detroit: Hamilton Anderson Associates.

Harnik, P. (2006). The Excellent City Park System: What Makes It Great and How to Get There. In R. H. Platt (Ed.), The Humane Metropolis: People and Nature in the 21st Century City (pp. 47-60). Amherst, MA: University of Massachusetts Press.

Justus, J. (2002). A History of Belle Isle. Detroit: Friends of Belle Isle.

Kiley, D. U., Tyndall, I., \& Walker, P. K. (1976). Belle Isle Park, Detroit Michigan, Master Plan Draft. Charlotte, VT: Landscape Design, Architecture, Planning.

Lane, M. B. (2005). Public Participation in Planning: An Intellectual History. Australian Geographer, 36, 283-299. https://doi.org/10.1080/00049180500325694

Leone, M., Barnes, M., \& Sharpe, E. (2015). What Gets Plans off the Shelf? A Case Study of Municipal Recreation Plan Implementation. Journal of Park and Recreation Administration, 33, 51-68. https://doi.org/10.18666/JPRA-2015-V33-I4-6470

Levy, J. M. (2009). Contemporary Urban Planning (8th ed.). Upper Saddle River, NJ: Pearson Education.

Madden, K. (2001). Public Parks, Private Partners. Project for Public Spaces Inc.

McNeur, C. (2017). Parks, People, and Property Values: The Changing Role of Green Spaces in Antebellum Manhattan. Journal of Planning History, 16, 98-111. https://doi.org/10.1177/1538513216657563

Michigan Department of Natural Resources (2014). Belle Isle Becomes a State Park Today, Improvements Continue. Lansing, MI: Michigan Department of Natural Resources.

https://web.archive.org/web/20140512214819/http://www.michigan.gov/dnr/0\%2C457 0\%2C7-153-10371_10402-321698--\%2C00.html

Michigan Municipal League (2013). Dequindre Cut Greenway. http://placemaking.mml.org/how-to/dequindre-cut/

Muller, P. O. (1995). Transportation and Urban Form: Stages in the Spatial Evolution of the American Metropolis. In S. Hanson (Ed.), The Geography of Urban Transportation (pp. 26-52). New York, NY: The Guilford Press.

Olmsted, F. L. (1884). Belle Isle: After One Year. Brookline, MA: Kessinger Publishing, LLC.

Pack, A., \& Schanuel, S. (2005). The Economics of Urban Park Planning. Parks \& Recreation, 40, 64-184.

Rodriguez, M., \& Featherstone, T. (2003). Detroit's Belle Isle: Island Park Gem. Charleston, SC: Arcadia Publishing.

Sugrue, T. J. (2007). Motor City: The Story of Detroit. New York, NY: The Gilder Lehrman Institute of American History.

https://www.gilderlehrman.org/history-by-era/politics-reform/essays/motor-city-story$\underline{\text { detroit }}$ 
Sugrue, T. J. (2015). The Origins of the Urban Crises. Princeton, NJ: Princeton University Press.

Thomas, J. M. (2015). Redevelopment in Detroit: Spatial Evolution. In J. M. Thomas, \& H. Bekkering (Eds.), Mapping Detroit (pp. 51-74). Detroit, MI: Wayne State University.

Webster, M. (n.d.). Milieu. https://www.merriam-webster.com/dictionary/milieu

Zanen, R. V. (1972). Park Priorities. Detroit, Michigan: Detroit Free Press. 